\title{
根粒菌の進化と共生の機構にせまる共生プラスミドの全構造
}

根粒菌はマメ科植物に根粒や茥粒を 形成し, 空中窒素の固定を行なうグラ 么陰性の共生細菌である. 根粒形成や 窒素固定に関わる共生遺伝子は，一般 に, Rhizobium 属根粒菌ではプラスミ ド上に, Azorhizobium 属とBradyrhizobium 属根粒菌ではクロモソー ム上に存在している. 最近, Freiberg $ら^{(1,2)}$ は, ニューギニアから分離され た広宿主域の Rhizobium sp. NGR234 株の共生プラスミド pNGR234a （536 kb）の全 DNA シークエンスを 決定した。これは，近年全構造が明ら かにされている微生物のゲノムサイズ に比較すると大きいものではないが, 全構造が決定されたプラスミドとして は最も大きく, また共生に関わる一つ のレプリコンの全構造を明らかにした という点でュニークである.

共生プラスミド pNGR234a の全構 造を眺めてまず驚いたことは，原核生 物の “動く遺伝子”である挿入配列や モザイク様の配列が全配列の $18 \%$ と 多いことである，挿入配列などの可動 遺伝因子によって多数の遺伝子（67 個）が破壊され, 機能している遺伝子 の密度はレプリコン全体の $78 \%$, 他 の原核生物のゲノムの值 $(85 \sim 92 \%)$ と 比較して低い。また，pNGR234a の複 製や接合伝達に関わる遺伝子群が Agrobacteriumの Ti プラスミドと
きわめてよく似ており, 共通の起源で あると考えられる. Ti プラスミドの類 似の細菌への接合伝達を制御している $N$-アセチル-Lーホモセリンラクトン 類は, 細菌のフェロモンとして注目を 集めているが, 実際 NGR234 株の培養 液中にも類似化合物が含まれていた。

各遺伝子群の GC 含量, 共生遺伝子 の順序, 挿入配列の分布などから, こ のプラスミドは, Agrobacterium の $\mathrm{Ti}$ プラスミド様の祖先型が, 窒素固 定に関連する遺伝子を過去の一時期に まとめて獲得し, 根粒形成遺伝子は最 近あっちこっちから何回も収集してき たように見える。単生生活のためには このプラスミドは必要なく, 転写, 翻 訳, 一次代謝に関わる遺伝子はまった く見つからなかった.したがって， pNGR234a は宿主植物との共生のた めに適応した遺伝子の貯蔵庫として “自由に”進化している途上であると想 像され，またその進化に挿入配列が深 く関わっていることを示唆している.

根粒菌と宿主植物の初期相互作用を めぐっては, フラボノイドやリポキチ ンオリゴサッカライドなどのシグナル 分子の関与が近年明らかにされてい る(3). しかし，これは両パートナー間の 初期の認識機構であって, 共生系成立 の中後期にもシグナル交換を含むいく つかの相互作用があるものと考えられ
てきた。一般に根粒形成遺伝子には nod box と呼ばれる共通のプロモー 夕配列が存在するが, pNGR234a には 新たに 12 個（合計 17 個）の nod box が見つかり, 共生領域の密度の高い転 写地図を作成したところ, 共生成立に 必要であると考えられる新たなシグナ ル伝達系の存在が明らかになった。一 つは, ラムノースに富んだリポポリサ ッカライドであり，もう一つは，動物 や植物病原菌にみられるタンパク分泌 機構 (Type III) の存在である.またバ クテロイドの発達やニトロゲナーゼ複 合体の合成に関与していると推定され る機能不明の遺伝子も多数存在してい た.これは, 根粒菌と宿主植物の共生 成立過程を理解するために，根粒菌側 からの遺伝解析の余地もまだかなり残 されていることを意味し, 今後の面白 い展開が期待される。その他にも，P450 遺伝子群の存在や第 2 のプラスミ ドやクロモソームへの共生遺伝子の分 配など面白いトピックがあるが，興味 のある方は原報あるいはWWWで公 開されている詳細な情報 (http:// genome.imb - jena.de/archives. html）を見ていただきたい.

根粒菌は, 土壌中においては従属栄 養細菌として他の土壤細菌と競合しな がら自由生活を営んでいる。しかし， 宿主植物の感染に成功すると, 通常 1 
つの根粒菌細胞が約 1 億倍の根粒バク テロイド細胞になる。したがって，根 粒菌の共生に伴う遺伝的選択圧は非常 に大きいと言える。このような根粒菌 のライフスタイルが, 共生プラスミド の進化に一役買っているのであろう.
近年多用されている抗生物質や農薬の 強い選択圧のもとで, 多剤而性プラス ミドや分解系プラスミドの存在がクロ ーズアップされているが，このような プラスミドも共生プラスミドと同様に 進化してきたのではないだろうか.
1) C. Freiberg et al. : Nature, 387, 394 (1997).

2) A. Downie: Nature, 387, 352 (1997).

3）南沢 究, 遊橋健一：化学と生物, 34 , 345 (1996)

(南沢 究, 東北大学遺伝生態研究セ ンター)

\section{高等植物におけるシグナルとしての “リン酸”}

すべての生物で，リン (P)はその主 要な構成元素となっている。植物で は, 乾物 $1 \mathrm{~g}$ に 0.5 15 mg 含まれ,リ ン酸イオン, アデニル酸, 糖リン酸, ヌクレオチドなど代謝産物として，ま たフィチン酸, リン酸塩など貯蔵物質 として,さらにタンパク質のリン酸化 など制御因子としての機作が知られて いる。このため, 植物のリン酸吸収が 少なく，体内のリン酸レベルが低下す ると生長が抑制される．作物では生産 のための多量必須元素として窒素，力 リウムとともに三大肥料要素とされて いる.

植物はリン酸欠乏下におかれると， 様々な反応を示す，その多くは“リン 酸”に特有の現象であり，シグナル“リ ン酸”に反応して, 植物体でのレギュ レーションがなされている，培地から のリン酸, 硝酸, 硫酸イオンの供給を 一時停止し, 再度供給すると, 停止し ていたイオンの吸収活性が増大するこ とが知られている。これに対し Muchhal ら ${ }^{(1)}$ は, アラビドプシスの根で発 現する高親和性 $\left(K_{\mathrm{m}}\left(\mathrm{P}_{\mathrm{i}}\right)\right.$ が $\mu \mathrm{M}$ のオー
ダー）のリン酸トランスポーターを確 認し，この発現がリン酸欠乏で誘導さ れること報告している.

多くの土壤では, リン酸はアルミニ ウムや鉄と結合し，植物が吸収できる 可溶性のリン酸イオンとなっていな い。植物がこのようなりン酸可給性の 低い培地におかれると，クエン酸，リ ンゴ酸などの有機酸を根から放出す る. 有機酸に伴うプロトンの放出によ る根周辺の土壤 $\mathrm{pH}$ の低下や有機酸に よるメタルのキレート反応の結果, 植 物が吸収できるリン酸イオンが増大す る. リン酸欠乏下のルーピン, トマト, ナタネの根ではホスホエノールピルビ ン酸カルボキシラーゼ活性が増大し, 炭酸ガスの暗固定によりリンゴ酸，コ 八ク酸, クエン酸が数倍から数十倍生 成され，根から放出されることになる。 Johnson ら ${ }^{(2)}$ によれば, リン酸欠乏下 のルーピンの根では側根の異常化 (protenoid rootsの発達) に伴って, ホスホエノールピルビン酸カルボキシ ラーゼの mRNA が増加してきてお り，これにはオーキシンやサイトカイ
ニンなどの植物ホルモンの関与やカル ボキシラーゼの活性化へのタンパク質 リン酸化が想定されている.

一方，植物体内でのリン酸の濃度の 低下によっては，リン酸を必要としな い解糖系や呼吸への変換 ${ }^{(3)}$ や，リン酸 を遊離すべく酸性ホスファターゼ，ア ルカリ性ホスファターゼが活性化され る.リン酸欠乏で誘導される細胞内 酸性ホスファターゼには phytase, phosphoglycolate phosphatase, phosphoenolpyruvate phosphatase, phosphotyrosylprotein phosphatase など，貯蔵リン酸やリン含有化合物の 分解に関与する基質特異的な酵素が多 い(4)。一方，リン酸欠乏下では酸性木 スファターゼ(基質非特異的とされる) が根外に多く放出されるようになり， 根圈の有機態のリン酸エステルを分解 してリン酸を生成し，植物が吸収する 適応反応がみられる。

植物がリン酸や窒素欠乏の培地にお かれると, 茎葉部よりも根部の生長が 相対的に促進されること（乾物の分配 が茎葉部よりも根部に多くなること） 